\title{
PENERAPAN MODEL KIRKPATRICK UNTUK EVALUASI PROGRAM DIKLAT TEKNIS SUBTANTIF MATERI PERENCANAAN PEMBELAJARAN DI WILAYAH KERJA PROVINSI KEPULAUAN RIAU
}

\author{
Yetti Nurhayati \\ Widyaiswara Ahli Muda
}

\begin{abstract}
ABSTRAK
Evaluasi yang mengunakan Model evaluasi Kirkpatrick dengan 4 level (Kirkpatrick Four Levels Evaluation Model) dilakukan bertujuan untuk mengetahui efektivitas program Diklat Teknis Subtantif Materi Perencanaan Pembelajaran di Wilayah Kerja Provinsi Kepulauan Riau. Data diperoleh melalui instrumen observasi, wawancara, dan dokumentasi serta dianalisis menggunakan teknik deskriptif kualitatif. Wawancara dilakukan kepada peserta diklat, atasan peserta diklat yakni kepala madrasah, dan teman sejawat peserta diklat yakni guru. Hasil evaluasi ini adalah bahwa penilaian pada level 1 reaksi, hasil reaksi peserta terhadap panitia penyelenggara dan narasumber sangat tinggi. Hanya perlu perhatian persiapan bahan materi pelajaran perlu disiapkan di awal diklat dan perlengkapan ATK (alat tulis kantor) seperti flashdisc perlu di cek kembali. Pada level 2 belajar, kemampuan kompetensi sikap, pengetahuan, dan keterampilan peserta sangat signifikan penilaiannya. Pada level 3 perilaku, pelaksanaan evaluasi dilakukan setelah peserta kembali ke tempat kerjanya masing-masing. Ada peningkatan perubahan perilaku dari alumni diklat dari sebelum diklat dan setelah diklat. Perubahan perilaku seperti kedisiplinan kehadiran, cara berpakaian, memotivasi teman sejawat, berkomunikasi dengan baik, serta ketepatan dan kecepatan menyelesai tugas-tugas sehari-hari. Pada level 4 dampak, ada peningkatan kinerja alumni diklat. Alumni mampu membimbing dan mendesiminasi ilmu yang telah didapat dari diklat kepada sesama teman sejawatnya, mampu mengembangkan metode dan media pembelajaran dalam proses belajar mengajar, dan pembuatan Rancangan Program Pembelajaran (RPP) menjadi lebih baik.
\end{abstract}

Kata Kunci: Evaluasi, Kirkpatric, Pendidikan dan Latihan.

\section{ABSTRACT}

Evaluations using Kirkpatrick's evaluation model with 4 levels (Kirkpatrick Four Levels Evaluation Model) were conducted to find out the effectiveness of the Subtitical Technical Education and Training Program in the Riau Islands Province Work Area. Data were obtained through observation, interviews, and documentation instruments and analyzed using qualitative descriptive 
techniques. The interviews were conducted for the training participants, the training participants' superiors, namely the Madrasah Head, and the peer training participants, namely the teacher. The result of this evaluation is that the assessment is at level 1 reaction, the result of the reaction of the participants to the organizing committee and the resource person is very high. Just need attention to preparation of learning material needs to be prepared at the beginning of the training and equipment such as flashdisc need to be checked again. At level 2 learning, competency skills in attitudes, knowledge, and skills of participants are very significant. At level 3 behavior, the evaluation is carried out after the participants return to their respective workplaces. There is an increase in behavior changes from the training alumni from before the training and after the training. Behavioral changes such as attendance discipline, how to dress, motivate peers, communicate well, and the accuracy and speed of completing daily tasks. At level 4 impact, there is an increase in the performance of the training alumni. Alumni are able to guide and disseminate the knowledge that has been gained from training to their peers, be able to develop learning methods and media in the teaching and learning process, and make the Learning Program Design better.

Keywords: Evaluation, Kirkpatrick, Education and Training

\section{Pendahuluan}

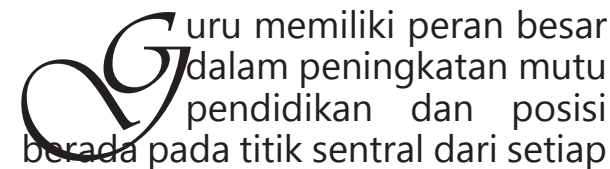
usaha perbaikan pendidikan yang diarahkan pada perubahan seluruh aspek pendidikan. Undangundang Republik Indonesia Nomor 14 Tahun 2005 tentang Guru dan Dosen Pasal (8) mengatur bahwa guru wajib memiliki kualifikasi akademik, kompetensi, sertifikat pendidik, sehat jasmani dan rohani, serta memiliki kemampuan untuk mewujudkan tujuan pendidikan nasional. Selanjutnya Peraturan Pemerintah Nomor 19 Tahun 2005 tentang Standar Nasional Pendidikan Pasal 28 ayat (3) bahwa guru diharuskan memiliki empat kompetensi, yakni kompetensi kepribadian, pedagogi, sosial, dan profesional. Berdasarkan Undang- undang dan peraturan pemerintah ini, maka kualitas guru madrasah perlu ditingkatkan.

Dalam upaya meningkatkan
kualitas kompetensi guru
madrasah, yaitu melalui kegiatan
pendidikan dan pelatihan

(Diklat). Yang secara umum tujuannnya adalah meningkatkan pengetahuan, keterampilan, dan sikap serta meningkatkan kualitas dan produktivitas guru secara keseluruhan. Upaya ini dilakukan melalui sistem diklatyang bervariasi dan berjenjang yang bertujuan untuk mempercepat tercapainya standar mutu guru, sehingga harus dilakukan secara terencana. intensif, efektif dan efesien.

Pada kenyataannya, tidak semua guru-guru di daerah 
seluruh Indonesia. bisa merasakan menjadi peserta diklat khususnya di Pusdiklat Tenaga Teknis Pendidikan dan Keagamaan Jakarta. Keterbatasan kuota peserta diklat pada setiap angkatan diklat menjadi kendala untuk dapat mengikuti kegiatan diklat. Setiap provinsi hanya dapat diwakilkan 1 orang saja. Salah satu penyebabnya yaitu tingginya biaya transportasi. Hal semacam ini menjadi kendala dalam pemerataan peningkatan kompetensi para guru di berbagai daerah, yang berimbas pula pada kemajuan tingkat pendidikan siswa-siswa di madrasah seluruh Indonesia.

Pusdiklat Tenaga Teknis Pendidikan dan Keagamaan melakukan terobosan memperluas akses diklat dengan cara menyelenggarakan Diklat Teknis Subtantif Materi Perencanaan Pembelajaran di Wilayah Kerja Provinsi Kepulauan Riau. Diklat yang dilaksanakan di luar kampus tersebut dimaksudkan agar daerah-daerah yang lebih terbatas akses diklatnya disebabkan tingginya biaya transportasi mendapat kesempatan khusus mengikuti diklat. Dengan adanya Diklat Teknis Subtantif Materi Perencanaan Pembelajaran di Wilayah Kerja Provinsi Kepulauan Riau, kepesertaan diklat reguler di dalam kampus yang biasanya terwakili oleh hanya satu orang dari tiap Provinsi untuk satu angkatan diklat berjumlah 30 orang peserta, tapi dengan program Diklat Teknis Subtantif Materi Perencanaan Pembelajaran Di Wilayah Kerja Provinsi Kepulauan Riau dapat mengakomodir 40 orang peserta.

Program Pendidikan dan pelatihan (Diklat) merupakan program pelatihan yang memerlukan evaluasi yang tujuannya untuk mengetahui keberhasilan pelaksanaan diklat. Model evaluasi program yang khusus diciptakan untuk pelatihan adalah Model Evaluasi Kirkpatrick. Model ini dipilih karena telah banyak digunakan untuk mengevaluasi program-program pelatihan di seluruh dunia.

Model evaluasi Kirkpatrick dalam pelaksanaannya menggunakan 4 tahap yaitu 1) reaksi, 2) belajar, 3) Perilaku, dan 4) Dampak. Pada tahap 1) reaksi, dan 2) belajar telah dilaksanakan evaluasinya pada proses Program Diklat Teknis Subtantif Materi Perencanaan Pembelajaran di Wilayah Kerja Provinsi Kepulauan Riau berlangsung. Alasan mengapa telah dilaksanakan karena pada tahap 1-reaksi bertujuan untuk mengetahui reaksi peserta terhadap program diklat, tahap 2-belajar juga bertujuan untuk mengetahui peningkatan kompetensi peserta baik dalam sikap, pengetahuan dan keterampilan. Tahap 3-Perilaku, menilai perubahan perilaku alumni peserta setelah kembali di unit kerjanya. Tahap 4-Dampak, menilai alumni peserta dari segi dampak 
kinerja setelah mengikuti Program Diklat Teknis Subtantif Materi Perencanaan Pembelajaran Di Wilayah Kerja Provinsi Kepulauan Riau apakah memberikan kontribusi yang lebih baik untuk dirinya, siswa maupun di tempat kerja sendiri atau Madrasah.

\section{Metode Penelitian}

Metode Penelitian yang digunakan metode Evaluasi dengan pendekatan kombinasi kualitatif dan kuantitatif. Pendekatan kombinasi ini digunakan untuk mengumpulkan data secara mendalam dan menghasilkan fakta yang lebih komprehensif. Fokus evaluasi ini juga untuk mendapatkan data yang lengkap, mendalam, dan memberikan jawaban yang tepat terhadap masalah yang akan diteliti dengan menggunakan metode pendekatan kualitatif dan kuantitatif. Pendekatan ini diarahkan untuk mendeskripsikan data secara holistik.

Data kualitatif dan kuantitatif yang diperoleh dari berbagai sumber dengan menggunakan teknik pengumpulan data yang bermacam-macam (triangulasi), dilakukan secara terus menerus. Proses mencari dan menyusunya, data yang diperoleh dari hasil wawancara, catatan lapangan, dan bahan-bahan lain.

\section{Pembahasan}

Secara umum evaluasi ini bertujuan untuk menjelaskan tingkat keberhasilan dari suatu program Diklat Teknis Subtantif Materi Perencanaan Pembelajaran Di Wilayah Kerja Provinsi Kepulauan Riau. Pada akhirnya menuju perbaikan dan penyempurnaan serta dapat dijadikan acuan dalam menentukan kebijakan program di Pusdiklat Tenaga Teknis Pendidikan dan Keagamaan Kementerian Agama.

Secara khusus sebagai penelitian evaluasi, evaluasi ini memiliki tujuan mengetahui berbagai dimensi yang dapat mempengaruhi efektivitas Program Diklat Teknis Subtantif Materi Perencanaan Pembelajaran di Wilayah Kerja Provinsi Kepulauan Riau. Tujuan tersebut antara lain:

1. Mengetahui reaksi peserta terhadap pelaksanaan program Diklat di Wilayah Kerja Diklat Teknis Subtantif Materi Perencanaan Pembelajaran di Wilayah Kerja Provinsi Kepulauan Riau. Kegiatan evaluasi yang dilakukan meliputi: 1) reaksi peserta terhadap panitia penyelenggara dan 2) reaksi peserta terhadap narasumber.

2. Mengetahui pencapaian hasil belajar peserta berupa peningkatan sikap, pengetahuan, dan keterampilan setelah mengikuti pelaksanaan Diklat Teknis Subtantif Materi Perencanaan Pembelajaran di Wilayah Kerja Provinsi Kepulauan Riau. 
3. Mengetahui perubahan pada tahap perilaku peserta Diklat di Wilayah Kerja Diklat Teknis Subtantif Materi Perencanaan Pembelajaran di Wilayah Kerja Provinsi Kepulauan Riau di lingkungan tempat peserta bertugas.

4. Mengetahui dampak diklat dilihat dari segi kinerja peserta (lulusan) pada Diklat Teknis Subtantif Materi Perencanaan Pembelajaran di Wilayah Kerja Provinsi Kepulauan Riau setelah kembali di lingkungan tempat peserta bertugas.

\section{Model Evaluasi Empat Level Kirkpatrick}

Model evaluasi empat level dikenal pertama kali pada tahun 1959 ketika Donald L. Kirkpatrick menulis empat seri artikel dengan judul "Tecniques for Evaluating Training Programs" yang diterbitkan dalam Training and Development, the journal of The American Society for Training and Developmet (ASTD). Artkel-artikel tersebut menggambarkan evaluasi empat level yang diformulasikan oleh Kirkpatrick berdasarkan konsep dari desertasi beliau pada University of Wiconsin, Madison. Kirkpatrick, D., L. \& Kirkpatrick J., D. (2006) mengemukakan tiga alasan spesifik dalam melakukan evaluasi program pelatihan, yaitu: untuk menjustifikasi keberadaan anggaran pelatihan dengan memperlihatkan bagaimana program pelatihan tersebut berkontribusi pada tujuan dan sasaran organisasi. Penentuan apakah suatu program pelatihan dilanjutkan atau tidak, serta memperoleh informasi mengenai bagaimana cara meningkatkan program pelatihan dimasa datang. Metode evaluasi empat level merepresentasikan sebuah sekuen dari setiap tahapan untuk mengevaluasi program pelatihan. Sekuen yang dimaksud adalah setiap level harus dilakukan secara bertahap. Hal tersebut karena setiap level dalam model empat level adalah penting dan setiap level memberi dampak pada level berikutnya. Empat level tersebut adalah:

\section{Level 1 Reaksi}

Tahap reaksi pada dasarnya merupakan evaluasi terhadap kepuasan peserta diklat terhadap berbagai kegiatan yang diikuti. Reaksi peserta tersebut dapat menentukan tingkat ketercapaian tujuan dari penyelenggaraan diklat. Program penyelenggaraan diklat dianggap berhasil apabila peserta diklat merasa puas terhadap seluruh unsur yang terlibat dalam proses penyelenggaraan.

Keberhasilan proses kegiatan pembelajaran tidak terlepas dari minat, perhatian, dan motivasi peserta diklat dalam mengikuti diklat. Peserta belajar lebih baik apabila mereka memberi reaksi positif terhadap lingkungan belajar. Ada dua jenis instrumen reaksi untuk mengevaluasi pada level 1 reaksi yaitu reaksi peserta terhadap penyelenggaraan dan narasumber.

Tujuan dari level reaksi ini untuk memberikan masukkan yang 
berharga kepada penyelenggara diklat dalam meningkatkan program pelatihan dimasa datang; memberikan saran dan masukkan kepada pengajar mengenai tingkat efektivitas mereka dalam mengajar; dapat memberikan informasi kepada para pembuat keputusan terkait dengan pelaksanaan program diklat; serta dapat memberikan informasi juga kepada narasumber yang dapat digunakan sebagai dasar untuk membuat standar pengajaran untuk program yang akan datang.

\section{Level 2 Belajar}

Pada level belajar, peserta diklat ini mempelajari pengetahuan atau keterampilan yang disampaikan dalam kegiatan pengajaran. Mengukur pembelajaran berarti menentukan satu hal atau lebih yang berhubungan dengan tujuan pelatihan, seperti pengetahuan apa yang telah dipelajari, keterampilan apa yang telah dikembangkan atau ditingkatkan, dan sikap apa yang telah berubah. Syafril Ramadhon dalam Jurnal Pusdiklat Migas ESDM (2012), ada langkah-langkah yang dilakukan dalam mengevaluasi di level belajar, adalah:
a. Mengevaluasi peningkatan
terkait keterampilan, dan perubahan sikap sebelum dan sesudah pelatihan.
b. Mengukur sikap menggunakan tes yang telah disepakati indikator-indikatornya
c. Mengukur pengetahuan menggunakan pretes dan postes.

d. Mengukur keterampilan menggunakan tes performa;

e. Hasil pengukuran tersebut untuk melakukan tidakan yang sesuai. Yang dimaksud tindakan yang sesuai dalam hal ini adalah melakukan tindakan konfirmatif dengan hasil evaluasi di level reaksi, apakah karena pengajar kurang komunikatif dalam menyampaikan materi, terkait strategi belajar yang tidak sesuai dengan harapan peserta, atau karena faktor-faktor lain di level-1 yang mungkin dapat menyebabkan peserta mengalami demotivasi dalam belajar, sehingga kekurangan evaluasi dalam reaksi dapat segera mendapat perhatian.

\section{Level 3 Perilaku}

Perilaku menurut Kirkpatrick D., L. (1998), mendefinisikan sebagai sejauh mana perubahan perilaku yang muncul karena peserta mengikuti program pelatihan. Evaluasi level-3 dilakukan untuk mengindetifikasikan sejauh mana materi dalam pelatihan diaplikasikan pada pekerjaan dan tempat kerja peserta. Menurut Tan, K. \& Newman, E. (2013), evaluasi perilaku mengukur pengetahuan, keterampilan, atau sikap apa yang dipelajari untuk diaplikasikan atau dipindahkan pada pekerjaan. Dari definisi tersebut di atas dapat diartikan tujuan dilakukannya evaluasi di tahap perilaku adalah untuk mengukur perubahan dalam perilaku kerja yang muncul karena pegawai tersebut mengikuti program pelatihan. 
Untuk dapat mengaplikasikan perubahan perilaku tersebut, menurut Kirkpatrick, D., L. (1998), terdapat empat kondisi yang diperlukan, yaitu: (1) seseorang harus mempunyai keinginan untuk berubah; (2) seseorang harus tahu apa yang harus dilakukan dan bagaimana cara melakukan hal tersebut; (3) seseorang harus bekerja dalam lingkungan kerja yang tepat; dan (4) serta seseorang harus mendapatkan penghargaan karena dia berubah.

Program diklat dapat memberikan kondisi pertama dan kedua dengan program pelatihan yang mendukung perubahan sikap sesuai dengan tujuan pelatihan dengan memberikan materi terkait pengetahuan, keterampilan, ataupun sikap. Tetapi untuk hal ketiga tentang lingkungan kondisi kerja yang tepat, berkaitan langsung dengan atasan dan lingkungan peserta.

\section{Level 4 Dampak}

Pelaksanaan pelatihan, tentunya bertujuan mendapatkan hasil yang baik, seperti peningkatan kualitas, produktivitas, atau tingkat keselamatan. Evaluasi hasil menurut Kirkpatrick, D., L. $(2006,134)$ dapat didefinisikan sebagai sebuah hasil akhir yang terjadi sebagai akibat peserta mengikuti program pelatihan. Langkah-langkah dalam melakukan evalausi di level-4 adalah:

1. Lakukan terlebih dahulu evaluasi di level-3.

2. Berikan waktu dalam melihat dampak muncul atau tercapai.
Tidak ada waktu yang spesifik dalam melakukan evaluasi hasil, sehingga dalam menentukan waktu pelaksanaan evaluasi harus mempertimbangkan berbagai faktor yang terlibat.

3. Dapat dilakukan dengan metode survei menggunakan kuisioner. ataupun wawancara terhadap peserta pelatihan dan pimpinan perusahaan.

4. Lakukan pengukuran, baik sebelum dan sesudah program pelatihan apabila memungkinkan.

5. Lakukan evaluasi ulangan pada waktu yang sesuai pada waktu yang sesuai.

6. Pertimbangan biaya yang dikeluarkan dengan hasil yang didapat.

7. Dapat menggunakan data sekunder, seperti data penjualan, data produksi, dan data lainnya yang mendukung hasil survei dalam menganalisi hasil.

Seperti yang sudah dijelaskan, bahwa dalam melakukan implementasi model evaluasi empat level, harus dilakukan secara sekuen, karena setiap level merupakan hal yang penting dan mempunyai dampak pada level berkutnya. Sebagai contoh, apabila dilakukan evaluasi langsung di level-3 (tanpa melakukan evaluasi di level-2), ketika hasil evaluasi mengindikasikan bahwa hanya sedikit peserta yang perilakunya berubah sesuai dengan tujuan pelatihan, maka kesimpulan yang muncul adalah bahwa program 
pelatihan tidak bagus, sehingga tidak lagi dilanjutkan atau dilakukan modifikasi. Hal tersebut adalah tidak tepat, karena dalam menerapkan perubahan perilaku terdapat faktor-faktor lain yang mempengaruhi seperti kondisi tempat kerja dan pimpinan peserta pelatihan. Faktor lain yang tidak kalah penting adalah dengan melihat hasil analisis evaluasi di level-2, sehingga dapat ditelusuri, apakah ketidakmampuan peserta sehingga bisa merubah perilakunya juga disebabkan oleh kurangnya pemahaman peserta terhadap materi. Alasan kurangnya peserta dalam memahami materi kemudian dapat juga ditelusuri dengan melihat hasil analisis peserta di level-1, apakah pemahaman materi yang kurang dari peserta karena disebabkan oleh ketidakpuasan peserta terhadap penyelenggaraan pelatihan atau karena kualitas pengajar yang kurang, sehingga peserta tidak mempunyai motivasi dalam belajar. Jadi dengan dilakukannya implementasi model empat level secara sekuen, terdapat ukuran lebih sebagai dasar analisis untuk menarik suatu kesimpulan.

\section{Pembahasan Hasil Temuan}

\section{Level Reaksi}

Tahap reaksi pada dasarnya merupakan evaluasi terhadap kepuasan peserta diklat terhadap berbagai kegiatan yang diikuti. Reaksi peserta tersebut dapat menentukan tingkat ketercapaian tujuan dari penyelenggaraan diklat. Program penyelenggaraan diklat dianggap berhasil apabila peserta diklat merasa puas terhadap seluruh unsur yang terlibat dalam proses penyelenggaraan.

Keberhasilan proses kegiatan pembelajaran tidak terlepas dari minat, perhatian, dan motivasi peserta diklat dalam mengikuti diklat. Peserta belajar lebih baik apabila mereka memberi reaksi positif terhadap lingkungan belajar. Ada dua jenis instrumen reaksi untuk mengevaluasi pada level 1 reaksi yaitu:

1. Reaksi peserta terhadap penyelenggaraan. Tujuannya untuk mengetahui kepuasan peserta diklat terhadap keberhasilan proses kegiatan pembelajaran yang tidak terlepas dari minat, perhatian, dan motivasi terkait dengan (a) kepesertaan; (b) Kepanitiaan; (c) Akomodasi; (d) Kurikulum; (e) Konsumsi; dan (f) Sarana Diklat.

2. Reaksi peserta terhadap narasmber. Tujuannya untuk mengetaui kepuasan peserta diklat terhadap Proses pembelajaran yang dilakukan dikaji dari beberapa aspek, yaitu materi yang diberikan, fasilitas yang tersedia dan narasumber. 


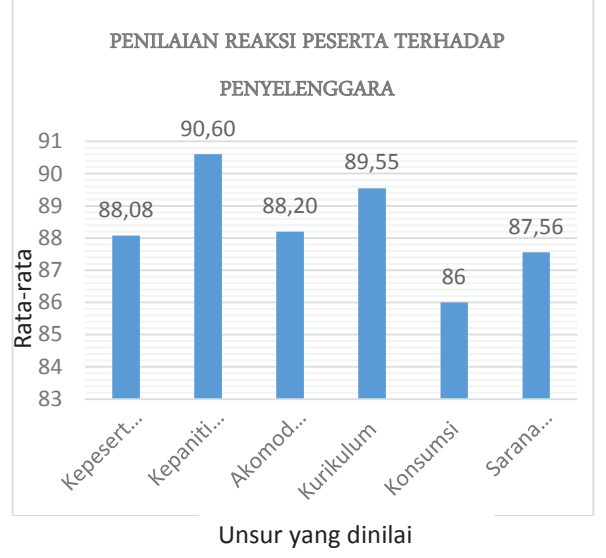

Hasil penilaian dari evaluasi peserta terhadap panitia penyelenggara adalah komponen dan nilai rata-rata terdiri dari yaitu (a) kepesertaan (penetapan, pemanggilan dan penegakkan disiplin peserta) 88,08; (b) Kepanitiaan (pelayanan, kedisiplinan, kerjasama dengan peserta, pelayanan terhadap narasumber dan sikap terhadap narasumber) 90,60; (c) Akomodasi (kebersihan dan kenyamanan) 88,20; (d) Kurikulum (jadwal diklat, materi diklat, manfaat materi diklat dan extrakurikuler) 89,55; (e) Konsumsi (Menu, penyajian dan higienis) 86,00; dan (f) Sarana Diklat (ruang kelas, alat bantu, dan bahan belajar) 87,56. Rata-rata keseluruhan hasil evaluasi reaksi peserta terhadap penyelenggara adalah 85,7. Nilai angka 85,7 menunjukkan pada kategori "Baik"

Berdasarkan evaluasi reaksi peserta terhadap Diklat ini dapat dikatakan efektif dan nyaman. Namun ada beberapa catatan yang perlu yang menjadi perhatian lebih lanjut atau belum sesuai dengan harapan peserta yaitu: konsumsi, ketersediaan bahan ajar dan flashdisc yang diberikan ada beberapa yang tidak berfungsi dengan baik atau maksimal.

Berdasarkan hasil observasi lapangan diketahui bahwa peserta cukup aktif setiap sesi. Namun masih ada sebagian kecil peserta yang kelihatannya mengantuk dalam beberapa sesi penyajian materi kemungkinan kondisi bulan puasa. Peserta selalu hadir pada setiap sesi dan mereka aktif dalam mengikuti sesi penyajian materi. Hasil wawancara menunjukkan bahwa peserta pada umumnya cukup antusias dalam mengikuti Diklat Teknis Subtantif Materi Perencanaan Pembelajaran di Wilayah Kerja Provinsi Kepulauan Riau.

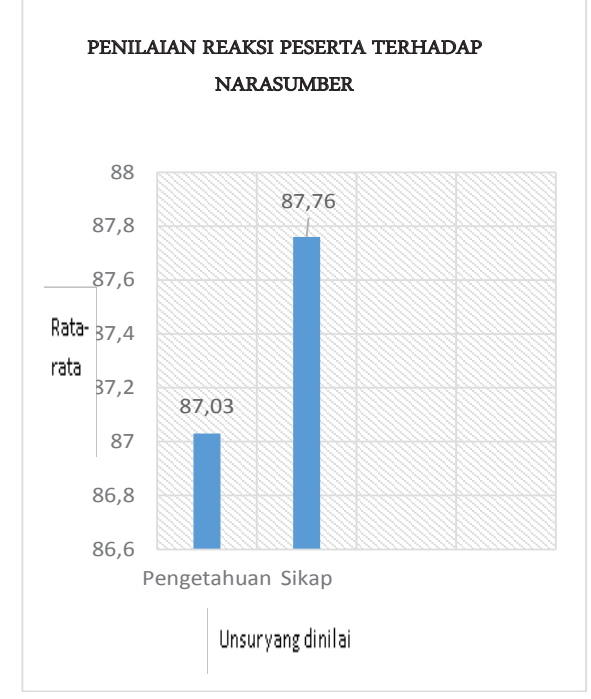


Hasil penilaian dari evaluasi peserta terhadap Narasumber dinilai "Baik" terbukti dengan perolehan nilai rata-rata kesuluruhan 88.37. narasumber/ widyaiswara berjumlah 2 orang yang terdiri dari Dra. Endang Sutisnowati, M.M dan Yetti Nurhayati, S.Pd. Komponen terdiri dari yaitu:

1. Segi pengetahuan yang mencakup indikator sebagai berikut: Pengetahuan dan keterampilan mengajar, penguasaaan materi, sistematika penyajian, penggunaan metode dan alat bantu pembelajaran. Nilai ratarata yang diperoleh 87,03 .

2. Segi sikap yang mencakup indikator sebagai berikut: etika, sikap terhadap peserta, cara menjawa pertanyaan peserta, penggunaan Bahasa, pemberian motivasi, disiplin waktu, keterampilan berpakaian serta kerjasama (TIM). Nilai rata-rata yang diperoleh 87,76.

Jadi total rata secara keseluruhan penilaian peserta terhadap narasumber 87,40. Angka tersebut di kategorikan "Baik"

Berdasarkan hasil dari wawancara terhadap peserta diperoleh data bahwa widyaiswara tidak hanya menjelaskan secara teori merancang program pembelajaran tetapi juga dengan contoh serta di aplikasikan dengan praktik mengajar yang sesuai dalam kurikulum 2013.

\section{Level Belajar}

Pada Tahap ini dilakukan evaluasi hasil pembelajaran, yang meliputi ketercapaian tujuan pembelajaran dan hasil belajar yang diharapkan dari proses pembelajaran. Bagi lembaga diklat khusunya Pusdiklat Tenaga Teknis Pendidikan dan Keagamaan hal ini sangatlah penting, dikarenakan keberhasilan dan komponen berikutnya terkait erat dengan komponen hasil pembelajaran ini. Adapun hasil belajar yang diujikan sesuai dengan mata diklat yang diajarkan dan tujuan dari pembelajaran pada Diklat Teknis Subtantif Materi Perencanaan Pembelajaran di Wilayah Kerja Provinsi Kepulauan Riau.

Mengukur keefektifan program pembelajaran, ada tiga aspek yang perlu untuk diukur, yaitu sikap, pengetahuan, dan keterampilan. Pada tahap belajar disini diharapkan ada perubahan dari peserta diklat pada ketiga aspek tersebut sesuai dari tujuan program diklat tersebut. Tanpa adanya perubahan sikap, peningkatan pengetahuan, maupun perbaikan keterampilan pada peserta didik maka program dapat dikatakan gagal. Penilaian evaluating learning ini ada yang menyebut dengan penilaian hasil (output) belajar. Oleh karena itu, dalam pengukuran hasil belajar (learning measurement) berarti penentuan satu atau lebih hal berikut, yakni: (1) perubahan sikap; (2) pengetahuan yang telah dipelajari; dan (3) keterampilan yang telah dikembangkan atau diperbaiki. Kualitas tes yang digunakan merupakan butir tes 
yang sesuai dengan kurikulum mata diklat. Semua materi yang diberikan juga sesuai dengan kebutuhan dan materi yang diajukan sesuia dengan kurikulumnya.

\section{Evaluasi pemebelajaran} Diklat Teknis Subtantif Materi Perencanaan Pembelajaran di Wilayah Kerja Provinsi Kepulauan Riau merupakan kegiatan yang terintegrasi dengan rancangan diklat. Otoritas Pusdiklat melingkupi penyusunan tes untuk seluruh mata diklat sampai kepada penetapan kelulusan melalui seperangkat tes yang berisikan pilihan ganda melalui pretes dan postes. Adapun kategorisasi kelulusan sampai pada pemberian Surat Tanda Tamat Pelatihan (STTP) semuanya dilakukan oleh Pusdiklat.

Penetapan

kelulusan peserta diklat berdasarkan evaluasi yang dilakukan selama proses pelaksanaan kegiatan pembelajaran Diklat Teknis Subtantif Materi Perencanaan Pembelajaran di Wilayah Kerja Provinsi Kepulauan Riau dilakukan teridiri dari beberapa aspek, yaitu:

a. Penilaian sikap peserta sebesar $30 \%$.

b. Penilaian pengetahuan peserta sebesar $40 \%$.

c. Penilaian keterampilan peserta sebesar 30\%.

Seperti yang telah dijelaskan sebelumnya, bahwa penentuan kualifikasi kelulusan peserta Diklat Teknis SubtantifMateri Perencanaan Pembelajaran di Wilayah Kerja Provinsi Kepulauan Riau dilakukan oleh panitia penyelenggara dan narasumber dari Pusdiklat Tenaga Teknis Pendidikan dan Keagamaan dengan melakukan rekapitulasi dengan batas nilai kelulusan akhir adalah di atas 76 (tujuh puluh enam).

Evaluasi pada tahap belajar digunakan untuk mengukur peningkatan kompetensi peserta sesuai dengan tujuan program Diklat Teknis Subtantif Materi Perencanaan Pembelajaran di Wilayah Kerja Provinsi Kepulauan Riau. Evaluasi di tahap belajar bertujuan untuk mengukur tingkat pemahaman peserta terhadap materi diklat atau sejauh mana daya serap peserta program Diklat Teknis Subtantif Materi Perencanaan Pembelajaran di Wilayah Kerja Provinsi Kepulauan Riau pada materi yang telah diberikan dari aspek sikap, pengetahuan dan keterampilan. Program Diklat Teknis Subtantif Materi Perencanaan Pembelajaran di Wilayah Kerja Provinsi Kepulauan Riau dikatakan berhasil ketika aspek tersebut mengalami perbaikan dengan membandingkan hasil pengukuran sebelum dan sesudah proses pembelajaran.

\section{PENILAIAN ASPEK SIKAP}

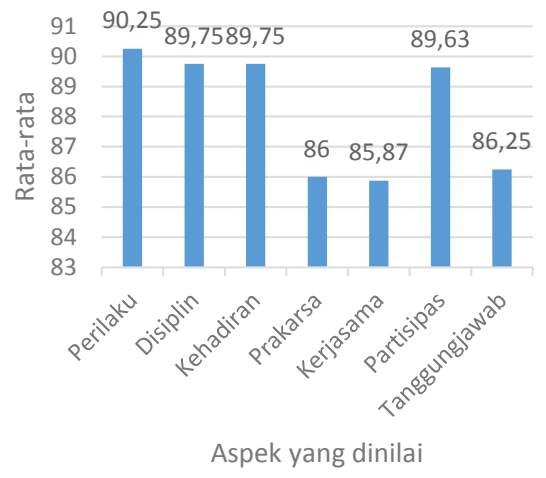


Setiap peserta diklat dinilai oleh panitia penyelenggara dan narasumber dalam 3 (tiga) aspek yaitu aspek sikap, pengetahuan dan keterampilan. Penilaian rinciannya sebagai berikut:

1) Penilaian pada aspek sikap.

Hasil penilaian dan instrumen yang dinilai antara lain: (1) Perilaku (jujur; menghargai perbedaan; ramah; dan berempati) 90,25; (2) Disiplin (berpakaian sesuai ketentuan dalam panduan; mentaati ketentuan administrasi; kesungguhan dalam belajar; dan mematuhi komitmen belajar 89,75; (3) Kehadiran (kehadiran tiap sesi) 89,75; (4) Prakarsa (memberikan ide atau gagasan dalam kelompok; memberikan solusi masalah; memelopori pelaksanaan tugas kelompok; dan memotivasi anggota kelompok) 86; (5) Kerjasama (terlibat aktif dalam penyelesaian tugas kelompok/kelas; mengajak orang lain dalam tugas kelompok/kelas; mematuhi kesepakatan kelompok/ kelas; dan bersikap kooperatif dengan widyaiswara/ narasumber/panitia dalam pelaksanaan diklat) 85,75; (6) Partisipasi (aktif bertanya; aktif menjawab; aktif menanggapi; memelopori pelaksanaan tugas kelompok; dan memotivasi anggota kelompok) 89,63; dan (7) Tanggung jawab (melaksanakan tugas; berani mengambil resiko; menjaga ketertiban kelas; dan menjaga nama baik individu, kelas, kelompok, lembaga) 86,25. Rata-rata hasil penilaian sikap peserta adalah 88,00. Berdasar nilai rata-rata tersebut maka dapat dikategorikan "Baik".

2) Penilaian pada aspek pengetahuan

\begin{tabular}{|c|c|c|}
\hline NAMA & PRETEST & POSTEST \\
\hline Rata-Rata & 44,60 & 85,40 \\
\hline
\end{tabular}

Kegiatan evaluasi pada aspek pengetahuan dilakukan melalui tes tertulis (pilihan ganda) untuk mengukur peningkatan pengetahuan dengan melaksanakan tes awal dan akhir. Dari perolehan hasil tes awal rata-rata 44,60 dan tes akhir rata-ratanya 85,40. Terlihat adanya kenaikan kompetensi pengetahuan peserta yang signifikan. Hasil angka akhir atau nilai tes akhir peserta dapat dikategorkan "Baik".

3) Penelitian pada aspek keterampilan

Penilaian dari segi keterampilan yaitu penilaian melalui praktik mengajar atau microteaching dan produk yang dihasilkan berupa dokumen Rencana Prgram Pembelajaran (RPP). Penilaian ini dilakukan untuk mengetahui pencapaian kompetensi materi perencanaan pembelajaran dapat dipraktikkan dalam 
proses microteaching dan produk yang peserta buat berupa penyusunan Rencana Program Pembelajaran (RPP), dan diperoleh rata-rata keseluruhan adalah 86,13. Nilai untuk keterampilan dikategorikan "Baik".

\section{Tahap Perilaku}

Perilaku menurut Kirkpatrick, D., L. $(2006,65)$ didefinisikan sebagai sejauh mana perubahan perilaku yang muncul karena peserta mengikuti program pelatihan. Evaluasi level-3 dilakukan untuk mengindetifikasikan sejauh mana materi dalam pelatihan diaplikasikan pada pekerjaan dan tempat kerja peserta. Menurut Tan, K. \& Newman, E., ( Vol. 30 No.3 Part 2 June 2013), evaluasi perilaku mengukur pengetahuan, keterampilan, atau sikap apa yang dipelajari untuk diaplikasikan atau dipindahkan pada pekerjaan. Dari definisi tersebut di atas dapat diartikan tujuan dilakukannya evaluasi di tahap perilaku adalah untuk mengukur perubahan dalam perilaku kerja yang muncul karena pegawai tersebut mengikuti program pelatihan.

Upaya untuk dapat mengaplikasikan perubahan perilaku tersebut, menurut Kirkpatrick, D., L (2006,102). Terdapat 4 (empat) kondisi yang diperlukan, yaitu: (1) seseorang harus mempunyai keinginan untuk berubah; (2) seseorang harus tahu apa yang harus dilakukan dan bagaimana cara melakukan hal tersebut; (3) seseorang harus bekerja dalam lingkungan kerja yang tepat; (4) serta seseorang harus mendapatkan penghargaan karena dia berubah

Pada tahap perilaku ini dilakukan penilaian terhadap peserta alumni Diklat Teknis Subtantif Materi Perencanaan Pembelajaran di Wilayah Kerja Provinsi Kepulauan Riau, untuk mengetahui perubahan perilaku setelah mengikuti diklat atau sekembalinya peserta ke tempat kerjanya masing-masing. Informasi tentang perubahan alumni peserta diklat diperoleh dari kepala madrasah dan teman sejawat dari alumni diklat.

Penilaian dilakukan terhadap 5 (lima) orang alumni dari MAN Tanjungpinang dan 5 (lima) orang dari MTsN Tanjungpinang. Berdasarkan hasil wawancara dan observasi yang telah dilakukan, diperoleh bahwa alumni menunjukkan perubahan yang sangat signifikan. Perubahan tersebut terdapat pada kedisiplinan meningkat, kehadiran lebih tepat waktu, penampilan berpakaian lebih rapi, kemandirian, pelayanan kepada siswa-siswa lebih melayani, sikap dalam kerja tim atau kelompok lebih koopratif, dan kecepatan dan ketepatan dalam menyelesaikan tugas lebih cepat serta tepat waktu, kesemuanya mengalami perubahan kearah yang lebih baik. Tingkat kedisiplinan ada yang 
sudah ada yang baik dari sebelum mengikuti diklat, namun ada juga yang masih belum berubah. Jarak rumah ke madrasah menjadi sebab keterlambatan kehadiran.

Ditinjau dari hasil wawancara kepada peserta memang terlihat jelas bahwa peserta Diklat Teknis Subtantif Materi Perencanaan Pembelajaran di Wilayah Kerja Provinsi Kepulauan Riau sangat antusias ketika kembali ke unit kerjanya masing-masing ketika dilakukan wawancara jawaban dari kepala madrasah dan teman sejawatnya, semua peserta telah mengalami perubahan perilaku relatif menjadi baik. Hal ini dapat diartikan bahwa tugas aktualisasi yang diberikan pada peserta Diklat Teknis Subtantif Materi Perencanaan Pembelajaran di Wilayah Kerja Provinsi Kepulauan Riau sepenuhnya dijalankan.

Beragam tanggapan untuk indikator perilaku di unit kerja dapat dikategorikan baik artinya pasca Diklat Teknis Subtantif Materi Perencanaan Pembelajaran di Wilayah Kerja Provinsi Kepulauan Riau, peserta dapat menjalankan tugasnya sesuai dengan kegiatan pengarahan tugas aktualisasi.

\section{Tahap Dampak}

Pelaksanaan program diklat, tentunya bertujuan mendapatkan hasil yang baik, seperti peningkatan kualitas, produktivitas, atau tingkat keselamatan. evaluasi di level dampak bertujuan apakah program pelatihan bermanfaat dalam mencapai tujuan organisasi. Hasil akhir dalam konteks evaluasi di level dampak mencakup hasil produksi yang meningkat, kepuasan pelanggan, peningkatan moral guru hubungan antara hasil positif yang diterima oleh madrasah dengan kegiatan pelatihan merupakan hal yang rumit, karena banyak aspek-aspek lain yang mempengaruhi hal tersebut dan pelatihan.

Pada tahap dampak ini juga dilakukan penilaian terhadap peserta alumni Diklat Teknis Subtantif Materi Perencanaan Pembelajaran di Wilayah Kerja Provinsi Kepulauan Riau, untuk mengetahui perubahan kinerja setelah mengikuti diklat atau sekembalinya peserta ke tempat kerjanya masing-masing. Informasi yang diperoleh dari kepala madrasah dan teman sejawat dari alumni diklat.

Penilaian dilakukan terhadap 5 (lima) orang alumni dari MAN Tanjungpinang dan 5 (lima) orang dari MTsN Tanjungpinang. Hasil dari wawancara dan observasi yang telah dilakukan, diperoleh bahwa penilaian dari kepala madrasah dan teman sejawat bahwa alumni mengalami peningkatan kinerja yang sangat signifikan.

Sebagai guru, peserta atau alumni Diklat Teknis Subtantif Materi Perencanaan Pembelajaran di Wilayah Kerja Provinsi Kepulauan Riau wajib melaporkan kegiatan aktualisasi yang dilakukan secara mandiri di unit kerja masing- 
masing. Ilmu yang telah diperoleh dari keikutsertaan diklat, sebagian besar telah didesiminasikan kepada teman sejawatnya. Pelaksanaan desiminasi di tempat kerja setelah melaksanakan diklat cukup beragam dalam hal pelaksanaannya, dikarenakan kesibukan dengan pekerjaannya sehari-hari yaitu mengajar.

Bimbingan serta arahan dari alumni kepada teman sejawat cukup besar kontribusinya, tidak hanya sekedar penambahan ilmu pengetahuan tapi juga perbaikan, terutama dalam hal pembuatan Rencana Program Pembelajaran (RPP) pada Kurikulum 2013.

Hasil wawancara kepada kepala madrasah dan teman sejawat terhadap alumni, terlihat jelas dampak Diklat Teknis Subtantif Materi Perencanaan Pembelajaran di Wilayah Kerja Provinsi Kepulauan Riau terhadap dampak kinerja dan keterampilan peserta di unit kerjanya masing-masing. Secara garis besar seluruh peserta alumni diklat sudah menyelesaikan tugas-tugas aktualisasi dan mengimplementasikan ilmu yang telah diterima pada saat diklat walaupun waktu pelaksanaan aktualisasi berbeda-beda.

Efektifitas pelatihan model Kirkpatrick adalah mengukur seberapa jauh pelatihan dan Pendidikan berpengaruh bagi pencapaian sasaran program Diklat yang berimbas pada capaian individual terhadap tempat tugas. Dapat dipahami, bahwa dalam Diklat Teknis Subtantif Materi Perencanaan Pembelajaran di Wilayah Kerja Provinsi Kepulauan
Riau lebih menekankan pada pengetahuan saja, tapi juga sikap dan keterampilan peserta secara umum sehingga dalam meningkatkan kinerjanya perlu secara khusus dinilai oleh kepala madrasah dan teman sejawatnya dengan indikator terpenting adalah laporan tugas aktualisasi diri yang diberikan oleh Pusdiklat Teknis Pendidikan dan Keagamaan.

Berdasarkan temuan evaluasi yang telah dikemukakan, jelas terlihat dampak dari Diklat Teknis Subtantif Materi Perencanaan Pembelajaran di Wilayah Kerja Provinsi Kepulauan Riau, jelas ada peningkatan kinerja alumni peserta dalam sistematika pekerjaan yang lebih baik.

\section{PENUTUP}

\section{Kesimpulan}

Berdasarkan hasil penelitian dan pembahasanya dapat diambil kesimpulan sebagai berikut:

1. Tahap reaksi

Evaluasi pada tahap reaksi menunjukkan peserta diklat sangatpuasterhadappelayanan dari panitia penyelenggara dan narasumber dari Diklat Teknis Subtantif Materi Perencanaan Pembelajaran di Wilayah Kerja Provinsi Kepulauan Riau. Catatan yang perlu diperhatikan adalah kelengkapan materi diklat/ modul untuk peserta serta mengecekan kembali fungsi flashdisc. 
2. Tahap Belajar

Evaluasi pada tahap belajar menunjukkan peserta sangat antusias dalam mengikuti proses pembelajaran. Penilaian sikap (perilaku, disipin, kehadiran, prakarsa, kerjasama, partisipasi dan tanggungjawab), pengetahuan (nilai pre dan post tes) dan keterampilan (microteaching) cukup memuaskan. Atas keberhasilan seluruh peserta diklat dinyatakan lulus dengan mendapatkan sertifikat tanda tamat pelatihan. Namun perlu ditingkatkan kemampuan peserta dalam menggunakan atau mengoperasikan laptop sehingga dalam menyelesaikan tugas yang diberikan tidak mengalami kendala waktu.

3. Tahap Perilaku

Evaluasi pada tahap perilaku menunjukkan alumni peserta diklat telah mengalami perubahan perilaku. Kedisiplinan penampilan kehadiran, kemandirian, berpakaian, kepada siswa-siswa, sikap dalam kerja tim atau kelompok dan kecepatan dan ketepatan dalam menyelesaikan tugas, kesemuanya mengalami perubahan kearah yang lebih baik.

Kedisiplinan kehadiran alumni peserta diklat, masih ada keterlambatan hadir dikarenakanjarak antara rumah dengan madrasah terlalu jauh. Namun secara garis besar, pasca diklat memberikan perubahan perilaku terhadap guru yang telah mengikuti dan Diklat Teknis Subtantif Materi Perencanaan Pembelajaran di Wilayah Kerja Provinsi Kepulauan Riau juga telah berkontribusi memberikan perubahan perilaku peserta menjadi lebih baik.

4. Tahap Dampak

Evaluasi pada tahap dampak menunjukkan adanya perubahan kinerja. Alumni telah mendesiminasi ilmu yang telah mereka terima, sehingga pengetahuannya bertambah menjadi lebih baik. Tidak hanya sekedar alumni itu sendiri tapi juga kepada teman-teman sejawatnya.

Kontribusi besar dari alumni peserta diklat terhadap kemajuan madrasah sangat berpengaruh besar dalam meningkatkan hasil belajar siswa-siswa cukup berdampak sangat baik.

\section{Rekomendasi}

Berdasarkan temuan pembahasan dan kesimpulan evaluasi program diklat di wilayah kerja materi perencanaan pembelajaran di Provinsi Kepulauan Riau di atas, maka dapat disusun rekomendasi evaluasi sebagai berikut:

1. Bagi Pusdiklat

Perlu ditambah kuota untuk diklat non regular seperti DDWK, untuk memberikan peluang kesempatan guru- 


guru madrasah untuk
mengikuti diklat terutama
guru-guru yang berada di
pelosok-pelosok desa.

2. Bagi Widyaiswara.

Perlu meningkatkan
kemampuan meningkatkan
kompetensi dan meng
update materi khususnya
pada materi Rencana
Program Pembelajaran (RPP)
berdasarkan revisi kurikulum
2013.

3. Bagi Madrasah dalam penerapan pengetahuan yang telah didapat bagi para peserta yang nantinya akan kembali di tempat tugas secara berkala, agar ilmu yang telah didapat tidak hilang begitu saja.

b. Perlu adanya kewajiban mendesiminasi bagi guru yang telah mengikuti diklat kepada guru-guru lainnya. Diharapkan dengan adanya desiminasi, untuk keseragaman dan persepsi tentang penyusunan Rencana Program Pembelajaran (RPP).

\section{DAFTAR PUSTAKA}

Arikunto, S. 2010. Prosedur Penelitian Suatu Penedekatan Praktik. Edisi 2010. Jakarta: Rineka Cipta.

Arikunto, S. 1998. Penelitian Program Pendidikan. Jakarta: PT Bina Aksara.

Kirkpatrick, L. Donald. 1998. Evaluating Training Programs, $2^{\text {nd }}$ Edition. San Fransisco: Berret-Koehler Publisher, Inc.

Kirkpatrick, Donald L. 2006. Implementing The Four Levels. San Fransisco: Berret-Koehler Publisher, Inc.

Nazir, Moh. 2011. Metode Penelitian. Bogor: Ghalia Indonesia.

Patton, Michael Quinn. 1990. Qualitative Evaluation and Research Methods. $2^{\text {nd }}$ ed. Newbury Park. California: Sage Publication

Peraturan Pemerintah Republik Indonesia Nomor 19 Tahun 2005 tentang Standar Nasional Pendidikan. Jakarta: Kementeriaan Pendidikan dan Kebuadayaan.

Scriven. M, 1974, Standart for Evaluation of Educational Programs and Products in G.D. Borich (Edo) Evaluation of Educational Programs and Products, Engelwood. Cliffs, M.J. Educational.

Sopacua, Evie, Didik Budijanto. 2007. Evaluasi 4 Tahap dari Kirkpatrick Sebagai Alat Dalam Evaluasi Pasca Pelatihan. Jakarta: Buletin Penelitian Sistem Kesehatan, volume 10, Nomor 4. 
Sugiyono. 2013. Metode Penelitian Kuantitatif, Kualitatif, dan Kombinasi. Bandung: Alfabeta.

Syafril Ramadhan, 2014. Penerapan Model Empat Level Kirkpatrick Dalam Evaluasi Program Pendidikan Dan Pelatihan Aparatur Di Pusdiklat Migas. Jakarta: Jurnal Pusdiklat Migas ESDM. Volume 06 No. 1

Tan, Kim and Newman, Eric. (2013). The evaluation of sales force training in retail Organizations: A test of Kirkpatrick's four level model. International Journal of Management Vol. 30 No.3 Part 2 June 2013

Tayibnapis, Farida Yusuf. 1989. Evaluasi Program Depdikbud, Dikti. Proyek Pengembangan Lembaga Pendidikan Kependidikan, Jakarta: Departemen Pendidikan dan Kebudayaan.

Undang-Undang Republik Indonesia. Nomor 11 Tahun 2005 Tentang Guru dan Dosen. Jakarta: Lembaran Negara Republik Indonesia Tahun 2005.

Wirawan. 2012. EVALUASI: Teori, Model, Standar, Aplikasi, dan Profesi. Jakarta: Rajawali Pers. 